\title{
Long-term stability of bronchial responsiveness to histamine
}

\author{
EF JUNIPER, PA FRITH, FE HARGREAVE \\ From the Firestone Regional Chest and Allergy Unit, Department of Medicine, St Joseph's Hospital and \\ McMaster University, Hamilton, Ontario, Canada
}

\begin{abstract}
Bronchial responsiveness to histamine was measured in 35 adult asthmatics whose symptoms were controlled on a minimum of medication. The tests were carried out on two occasions separated by 10-30 months. On each occasion the subjects had no symptoms of respiratory infection and no exposure to relevant allergens for at least six weeks. Bronchial responsiveness did not change in those who required no medication or inhaled salbutamol only to control their symptoms, but was significantly improved in those who required continuous treatment with both beclomethasone and salbutamol $(p=0.03)$. The results suggest that non-specific bronchial responsiveness remains similar over long periods when exacerbating factors are not present and that treatment with beclomethasone may reduce hyperresponsiveness.
\end{abstract}

The degree of non-specific bronchial responsiveness to histamine or methacholine correlates with the minimum amount of medication needed to control symptoms of asthma. ${ }^{1}$ In general the greater the hyperresponsiveness, the more medication is required to control symptoms. Exacerbations of asthma and heightened responsiveness can be induced by viral respiratory infection ${ }^{2}$ and exposure to allergens ${ }^{34}$ or volatile low molecular weight chemicals ${ }^{5} 6$ to which the person is sensitised. These events seem to lead to a requirement for more treatment; however, once the stimulus has been removed medication requirements often return to the same level as before. These points suggest that if non-specific bronchial responsiveness is measured when exacerbating factors are not present it should remain stable over long periods of time.

In this study we have examined the long-term stability of bronchial responsiveness to histamine in 35 adults with asthma. Measurements were made on two occasions separated by an interval of 10-30 months when symptoms were controlled by a minimum of medication and when symptoms of respiratory infection or exposure to allergen had not occurred for at least six weeks.

Address for reprint requests: Dr FE Hargreave, Regional Chest and Allergy Unit, St Joseph's Hospital, 50 Charlton Avenue East, Hamilton, Ontario, Canada, L8N 1 Y4.

\section{Methods}

The subjects were 35 of 51 adults with asthma who participated in an earlier study (table 1$).{ }^{1}$ All had previous or current episodic dyspnoea and wheezing and, from review of their records, showed variability in forced expired volume in one second $\left(F E V_{1}\right)$ of more than $20 \%$. Ten were atopic as indicated by one or more wheal and flare responses to prick tests with 16 common allergen extracts. All were non-smokers and none had features of other respiratory disease.

At the time of study their symptoms were controlled on a minimum of medication. Nine required no medication, 11 needed inhaled salbutamol (200 $\mu \mathrm{g})$ at least once a week up to four times a day, and 15 required additional beclomethasone dipropionate $(100 \mu \mathrm{g})$ once to four times a day. $\mathrm{FEV}_{1}$ was greater

Table 1 Patient characteristics

\begin{tabular}{lccc}
\hline & $\begin{array}{l}\text { No } \\
\text { medicalion }\end{array}$ & Salbutamol & $\begin{array}{l}\text { Beclomethasome } \\
+ \text { salbutamol }\end{array}$ \\
\hline Number & 9 & 11 & 15 \\
Age (yr) Mean & $30 \cdot 3$ & $41 \cdot 0$ & $54 \cdot 9$ \\
$\quad$ SD & $6 \cdot 5$ & $11 \cdot 4$ & $10 \cdot 7$ \\
Female & 6 & 6 & 7 \\
Initial FEV & & & \\
(\% predicted) & & $96 \cdot 4$ & $78 \cdot 7$ \\
$\quad$ Mean & $95 \cdot 9$ & $10 \cdot 8$ & $16 \cdot 7$ \\
$\quad$ SD & $7 \cdot 4$ & 3 & 0
\end{tabular}

*Indicated by one or more wheal and flare responses to skin prick tests with 16 common allergens. 
than $70 \%$ of predicted in all but five subjects at the time of the first inhalation test; in these it rose to above $80 \%$ predicted after salbutamol $(200 \mu \mathrm{g})$. No patients had symptoms of respiratory infection or exposure to an allergen to which they were sensitised for six weeks before each test.

\section{HISTAMINE INHALATION TEST}

The test was carried out by the method described by Cockcroft et al. ${ }^{7}$ Aerosols of the test solution were generated by a Wright nebuliser operated to give an output of $0.13 \mathrm{ml} / \mathrm{min}$ and a particle size of $1.5 \mu \mathrm{m}$ aerodynamic mass median diameter. Each aerosol was inhaled through the mouth by tidal breathing for two minutes. The first aerosol was saline and it was followed at five-minute intervals by two-fold increasing concentrations of histamine acid phosphate $(0.03$ to $16 \mathrm{mg} / \mathrm{ml})$. The response was measured by the FEV 1 at 0.5 and 1.5 min after each inhalation and further two-minute intervals if necessary to record the lowest value.

Inhalations were discontinued when the $\mathrm{FEV}_{1}$ had fallen $20 \%$ or more below the lowest post-saline value. The results were expressed as the provocation concentration causing a fall in $\mathrm{FEV}_{1}$ of $20 \%\left(\mathrm{PC}_{20}\right)$. This was obtained by linear interpolation of the last two points on the log dose-response curve.

\section{STUDY DESIGN}

A histamine inhalation test was carried out on two occasions separated by a period of at least 10 months. Before the initial test, the minimum medication requirements to control symptoms were established in a standard manner in every subject. ${ }^{1}$ Subjects remained on this level of treatment between the two tests unless there were exacerbations of symptoms, usually caused by allergen exposure or upper respiratory tract infection. Medications were increased to treat these; however when the provocation had been removed, treatment was reduced to the previously established minimum. All subjects required only their minimum medication requirements for at least six weeks before each test. On the test days, salbutamol was withheld for eight hours before inhalation but beclomethasone was continued in the regular dose.

Table 2 Summary of results

\begin{tabular}{|c|c|c|c|}
\hline & $\begin{array}{l}\text { No } \\
\text { medication }\end{array}$ & Salbutamol & $\begin{array}{l}\text { Beclomethasone } \\
+ \text { salbutamol }\end{array}$ \\
\hline $\begin{array}{l}\text { Time between tests } \\
\text { (months) } \\
\text { Initial } P C_{00}(\mathrm{mg} / \mathrm{ml})\end{array}$ & $16 \cdot 6$ & $13 \cdot 5$ & $22 \cdot 1$ \\
\hline Mean & $6 \cdot 07$ & $2 \cdot 45$ & 0.50 \\
\hline Final $\mathrm{PC}_{20} \stackrel{\text { SD }}{(\mathrm{mg} / \mathrm{ml})}$ & $4 \cdot 26$ & $1 \cdot 80$ & 0.49 \\
\hline $\begin{array}{l}\text { Mean } \\
\text { SD }\end{array}$ & $\begin{array}{l}7 \cdot 69 \\
3 \cdot 58\end{array}$ & $\begin{array}{l}3 \cdot 02 \\
2 \cdot 73\end{array}$ & $\begin{array}{l}1 \cdot 23 \\
1 \cdot 26\end{array}$ \\
\hline $\begin{array}{r}\text { Initial FEV } \\
\text { Mean } \\
\text { SD }\end{array}$ & $\begin{array}{l}2.89 \\
0.71\end{array}$ & $\begin{array}{l}2.98 \\
0.66\end{array}$ & $\begin{array}{l}2.09 \\
0.71\end{array}$ \\
\hline $\begin{aligned} & \text { Final FEV }_{1}(\mathrm{l}) \\
& \text { Mean } \\
& \text { SD }\end{aligned}$ & $\begin{array}{l}2 \cdot 88 \\
0 \cdot 81\end{array}$ & $\begin{array}{l}2.95 \\
0.72\end{array}$ & $\begin{array}{l}2.45 \\
0.74\end{array}$ \\
\hline
\end{tabular}

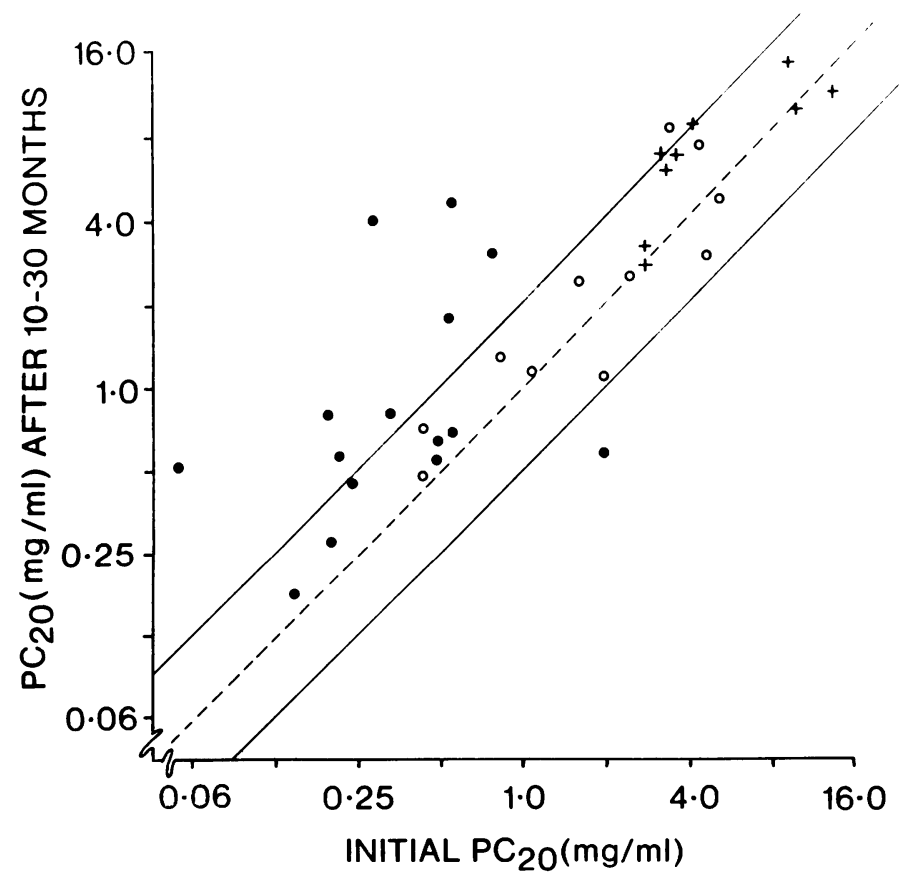

Fig 1 Changes in bronchial responsiveness to histamine over 10-30 months. Crosses $(+)$ represent patients on no medications, open circles $(\bigcirc)$ those requiring salbutamol alone, and closed circles (O) those requiring daily beclomethasone and salbutamol. The dashed line is the line of identity and the solid lines \pm one two-fold concentration of histamine. 


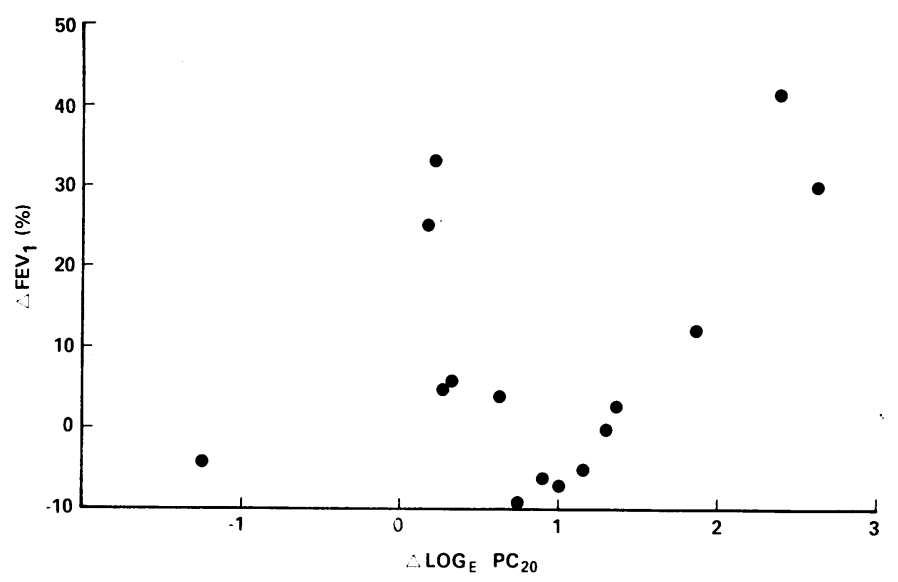

Fig 2 Relationship between change in $\log _{e} P C_{20}$ and change in baseline $F E V_{1}$ over 10-30 months, in patients on regular beclomethasone.

\section{ANALYSIS}

The changes in bronchial responsiveness between the two tests were examined using paired $t$ tests and significant changes were compared with other variables using correlation coefficient.

\section{Results}

The length of time between the two tests ranged from 10-30 months. Bronchial responsiveness to histamine (expressed as $\mathbf{P C}_{20}$ ) in the first test was compared to that measured in the second test (table 2, fig 1). There was no difference in patients on no medication ( $p>0.05$ ) and in those only requiring salbutamol ( $p>0 \cdot 1)$. There was a decrease in hyperresponsiveness (increase in $\mathrm{PC}_{20}$ ) in those on beclomethasone $(\mathrm{p}=0.03)$.

The reduction in hyperresponsiveness, in patients on beclomethasone, was weakly related to the changes in baseline $\mathrm{FEV}_{1}(\mathrm{r}=0.45)(\mathrm{fig} 2)$ and to the length of time between the two tests $(r=0.21)$.

\section{Discussion}

In the present study bronchial responsiveness to histamine in mild asthmatics, who required no medication or only salbutamol to control symptoms, did not alter over 10-30 months. Bronchial responsiveness in more severe asthmatics, requiring treatment with additional beclomethasone, improved slightly.

The first observation supports the contention that the degree of non-specific bronchial responsiveness, in individual adults with asthma, remains similar over long periods when symptoms are controlled and exacerbating factors are not present. It is known that respiratory infection ${ }^{8}$ and allergen exposure ${ }^{3}$ generally only heighten responsiveness for short periods, although there is suggestive evidence that these stimuli may induce more permanent changes. For example, intrinsic asthma beginning in adult life may follow an acute respiratory infection ${ }^{9}$ and patients with occupational asthma after sensitisation to western red cedar, can remain symptomatic and have non-specific bronchial hyperresponsiveness long after exposure has been discontinued.10 The observations in the present study therefore cannot be extended to indicate that bronchial responsiveness will always remain similar; increases or decreases in hyperresponsiveness may occur for long periods although they did not occur in the present study.

Treatment with salbutamol will decrease bronchial responsiveness acutely ${ }^{11}$ and must therefore be withheld before its measurement. There is also a possibility that regular use of salbutamol may decrease $\beta$-receptor function in bronchial smooth muscle, ${ }^{12}$ and this may lead to an increase in bronchial responsiveness. ${ }^{13}$ The results of the present study make this unlikely since responsiveness did not increase in patients whose asthma required treatment with salbutamol alone; this agrees with the findings of Peel and Gibson. ${ }^{14}$

The second observation raises the possibility that in more severe asthma, treatment with beclomethasone may reduce hyperresponsiveness. One cannot be certain about the validity of this result since the significance was not great and the study was not designed to examine this point. Previous reports of the effect of corticosteroids on bronchial responsiveness to histamine or methacholine have tended to suggest that they have little or no effect, ${ }^{15-17}$ and one even described an increase in responsiveness. ${ }^{18}$ However, these observations could be a result of subject selection and study design. An 
improvement in non-specific bronchial responsiveness might be expected where the corticosteroids are reversing changes which might contribute to the increase in responsiveness. These might include reduction in secretions tending to reduce airway calibre, reversal of epithelial shedding which might expose irritant receptors and increase reflex cholinergic bronchoconstriction, ${ }^{18}$ reduction of mucosal oedema and permeability, ${ }^{19}$ reduction of inflammatory reaction, 20 and increase in the number of $\beta$-adrenoceptors on smooth muscle. ${ }^{21}$ Alternatively the reduction in hyperresponsiveness may not be the result of an effect of beclomethasone but rather of spontaneous reduction in the degree of bronchial smooth muscle constriction at the time of the second test.

There was a weak relationship between improvement in bronchial responsiveness and increase in baseline $\mathrm{FEV}_{1}$. This could mean that the former influenced the latter or vice versa. However, the relationship was primarily caused by the influence of three of the 15 patients on beclomethasone who increased both $\mathrm{PC}_{20}$ and $F E V_{1}$ significantly; two patients had a significant increase in $\mathrm{FEV}_{1}$ but no change in $\mathbf{P C}_{20}$. It is therefore difficult to draw conclusions on the interrelationship of bronchial responsiveness and airway calibre.

We are grateful to our patients for participating in the study, and to Dr NL Jones and Dr J Dolovich for help with preparing the manuscript. This work was supported by a grant from the Medical Research Council of Canada.

\section{References}

1 Juniper EF, Frith PA, Hargreave FE. Airway responsiveness to histamine and methacholine: relationship to minimum treatment to control symptoms of asthma. Thorax $1981 ; 36: 575-9$.

${ }^{2}$ Little JW, Hall WJ, Douglas RG Jr, Mudholkar GS, Speers DM, Patel K. Airway hyperreactivity and peripheral airway dysfunction in influenza $\mathrm{A}$ infection. $\mathrm{Am}$ Rev Respir Dis 1978;118:295-303.

${ }^{3}$ Cockcroft DW, Ruffin RE, Dolovich J, Hargreave FE. Allergen-induced increase in non-allergic bronchial reactivity. Clin Allergy 1977;7:503-13.

${ }^{4}$ Cartier A, Bandouvakis J, Ryan G, Dolovich J, Hargreave FE. Asthma and increased non-allergic bronchial re- sponsiveness to methacholine during natural exposure to ragweed pollen. Am Rev Respir Dis 1980;121S:61A.

${ }^{5}$ Golden JA, Nadel JA, Boushey HA. Bronchial hyperirritability in healthy subjects after exposure to ozone. Am Rev Respir Dis 1978;118:287-94.

- Orehek J, Massari JP, Gayrard P, Grimaud C, Charpin J. Effect of short-term low level nitrogen dioxide exposure on bronchial sensitivity of asthmatic patients. $J$ Clin Invest 1976;57:301-7.

${ }^{7}$ Cockcroft DW, Killian DN, Mellon JJA, Hargreave FE. Bronchial reactivity to inhaled histamine: a method and clinical survey. Clin Allergy 1977;7:235-43.

${ }^{8}$ Empey DL, Laitinen LA, Jacobs L, Gold WM, Nadel JA. Mechanisms of bronchial hyperreactivity in normal subjects after upper respiratory tract infection. $\mathrm{Am} \mathrm{Rev}$ Respir Dis 1976;113:131-9.

${ }^{9}$ Rackemann FM. Intrinsic asthma. J Allergy 1940;11: 147-62.

${ }^{10}$ Lam S, Wong R, Yeung M. Non-specific bronchial reactivity in occupational asthma. J Allergy Clin Immunol $1979 ; 63: 28-34$.

11 Cockcroft DW, Killian DN, Mellon JJA, Hargreave FE. Protective effect of drugs on histamine-induced asthma. Thorax 1977;32:429-37.

12 Holgate ST, Baldwin CJ, Tattersfield AE. $\beta$-adrenergic agonist resistance in normal human airways. Lancet 1977;2:375-7.

${ }^{13}$ Ruffin RE, Frith PA, Anderton RC, Kumana CR, Newhouse MT, Hargreave FE. Selectivity of beta adrenoreceptor antagonist drugs assessed by histamine bronchial provocation. Clin Pharmacol Ther 1979;25: 536-40.

14 Peel ET, Gibson GJ. Effects of long-term inhaled salbutamol therapy on the provocation of asthma by histamine. Am Rev Respir Dis 1980;121:973-8.

15 Tiffeneau R, Dunoyer P. Action de la cortisone sur l'hypersensibilité cholinergique pulmonaire de l'asthmatique. La Presse Médicale 1956;64:719-21.

${ }_{16}$ Wolfe JD, Rosenthal RR, Bleeker E, Laube B, Norman PS, Permutt S. The effect of corticosteriods on cholinergic hyperreactivity. J Allergy Clin Immunol 1979; 63:162A.

${ }^{17}$ Easton JG. The effect of inhaled corticosteroids (CS) on cholinergic airway reactivity. $J$ Allergy Clin Immunol $1980 ; 65$ :182A.

${ }^{18}$ Arkins JA, Schleuter DP, Fink JN. The effect of corticosteroids on methacholine inhalation in symptomatic bronchial asthma. J Allergy 1968;41:209-16.

19 Boucher RC, Pare P, Gilmore NJ, Moroz LA, Hogg JC. Airway mucosal permeability in the Ascaris suumsensitive rhesus monkey. J Allergy Immunol 1977;60: 134-40.

${ }^{20}$ Fauci AS, Dale DC, Balow JE. Glucocorticosteroid therapy: mechanisms of action and clinical considerations. Ann Intern Med 1976;84:304-15.

${ }^{21}$ Mano K, Akbarzadeh A, Koesnadi K, Sano Y, Bewtra A, Townley $R$. The effect of hydrocortisone on beta adrenergic receptors in lung tissue. J Allergy Clin Immunol 1979;63:147. 